\title{
Avaliação eletrofisiológica da audição em gagos, pré e pós terapia fonoaudiológica*****
}

\author{
Eletrophysiological auditory evaluation in stutterers pre and post \\ treatment
}

\author{
Rosanna Mariangela Giaffredo Angrisani* \\ Carla Gentile Matas** \\ Ivone Ferreira Neves*** \\ Fernanda Chiarion Sassi*** \\ Claudia Regina Furquim de Andrade****
}

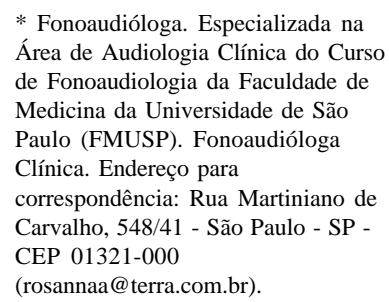

* Fonoaudióloga. Especializada na Área de Audiologia Clínica do Curso de Fonoaudiologia da Faculdade de Medicina da Universidade de São Paulo (FMUSP). Fonoaudióloga Clínica. Endereço para correspondência: Rua Martiniano de Carvalho, 548/41 - São Paulo - SP CEP 01321-000

(rosannaa@terra.com.br).

**Fonoaudióloga. Doutora em Distúrbios da Comunicação Humana pela Universidade Federal de São Paulo. Professor Adjunto do Departamento de Fisioterapia, Fonoaudiologia e Terapia Ocupacional da FMUSP.

***Fonoaudióloga. Doutora em Ciências pela FMUSP. Fonoaudióloga do Departamento de Fisioterapia, Fonoaudiologia e Terapia Ocupacional da FMUSP.

*****Fonoaudióloga. Professora Titular do Departamento de Fisioterapia, Fonoaudiologia e Terapia Ocupacional da FMUSP.

*****Trabalho Realizado Laboratório de Investigação Fonoaudiológica da Fluência, Motricidade e Funções Orofaciais do Departamento de Fisioterapia, Fonoaudiologia e Terapia Ocupacional da FMUSP.

Artigo Original de Pesquisa

Artigo Submetido a Avaliação por Pares

Conflito de Interesse: não

\section{Abstract}

Background: stuttering is a speech fluency disorder. Auditory evoked potentials (AEP) are electrophysiological tests that are being used as an instrument to establish the diagnosis of several disorders as well as to assess therapeutic outcomes. Aim: 1 - to characterize the AEP of individuals with stuttering in comparison to a control group; 2 - to verify the amelioration of these potentials post speech-language treatment. Method: the research sample was composed by 8 adult males with stuttering - research group (RG), with ages ranging from 18 to 30 years, and 8 normally fluent adult males - control group $(\mathrm{CG})$, within the same age range. Each group was assessed twice through brainstem auditory evoked response (BAER), middle latency response (MLR) and P300; assessments were carried out with a three months interval. Results: pre therapeutic outcomes - altered BAER results in one individual of the RG; altered MLR results in two individuals of the RG and in one individual of the CG; altered P300 results in two individuals of the RG. Comparison between pre and post speech-language treatment results indicate: BAER - decrease in wave I latency in $66.7 \%$ of the ears in the RG; MLR - a $16.7 \%$ decrease in wave PA latency in C3 for the RG; P300 latency decreased by $58.7 \%$ in both groups. Conclusion: the findings of this study indicate that MLR and P300 were the potentials that better characterized both groups and the three AEP expressed the neural plasticity post-speech-language treatment.

Key Words: Stuttering; Evoked Potentials, Auditory; Neuronal Plasticity.

\section{Resumo}

Tema: gagueira é um distúrbio da fluência da fala. Os potenciais evocados auditivos (PEA) são testes eletrofisiológicos que têm sido utilizados como instrumento para determinar o diagnóstico de diversas desordens, assim como para avaliar os resultados de processos terapêuticos. Objetivos: caracterizar os PEA de indivíduos gagos, comparando os resultados destes aos de indivíduos fluentes e verificar a evolução dos resultados destes potenciais frente à terapia fonoaudiológica. Método: estudo de oito indivíduos gagos (grupo pesquisa - GP) e oito fluentes (grupo controle - GC), na faixa etária de 18 a 30 anos. Cada grupo foi submetido a duas avaliações do potencial evocado auditivo de tronco encefálico (PEATE), de média latência (PEAML) e potencial cognitivo (P300), com intervalo de três meses entre elas. Resultados: préterapia fonoaudiológica: PEATE alterado em um indivíduo no GP. PEAML: alterado em 2 indivíduos no GP e em 1 no GC; P300 alterado em 2 indivíduos no GP. Na comparação pré e pós-terapia fonoaudiológica do PEATE, observou-se diminuição da latência da onda I em 66,7\% das orelhas do GP. Nos PEAML, a latência da onda Pa em C3 diminuiu em 16,7\% no GP. A latência do P300 diminuiu 58,3\% nos dois grupos. Conclusão: nesta pesquisa, o PEAML e o P300 foram os que melhor diferenciaram os dois grupos e os três PEA manifestaram a plasticidade neuronal pós-terapia fonoaudiológica.

Palavras-Chave: Gagueira; Potenciais Evocados Auditivos; Plasticidade Neuronal.

Recebido em 12.02.2009.

Revisado em 04.05.2009; 15.05.2009.

Aceito para Publicação em 15.05.2009.

Referenciar este material como:

1 Angrisani RMG, Matas CG, Neves IF, Sassi FC, Andrade CRF. Eletrophysiological auditory evaluation in stutterers pre and post treatment (original title: Avaliação $\sum 3$ eletrofisiológica da audição em gagos, pré e pós terapia fonoaudiológica). Pró-Fono Revista de Atualização Científica. 2009 abr-jun;21(2):95-100. 


\section{Introduction}

Stuttering is a speech fluency disorder (1). Studies have shown that stuttering affects multiple neural systems involved in speech (2) and also that the auditory development follows different patterns for person who stutters (PWS) and fluent individuals (3).

The auditory evoked potentials (AEP) are important on the assessment of the auditory pathways, especially in individuals with communication disorders. The AEP are objective tests and, therefore, do not require verbal responses from the patient (4). The therapeutic process progress can be monitored through changes in latency and amplitude of such potentials given the plasticity of Central Auditory Nervous System (5). In fact, systems that are responsible for learning have to maintain some ability to modify the neural "trigger" throughout life, otherwise no novel learning would happen $(6,7)$.

Several studies have used the AEP to assess and monitor the auditory pathway in PWS, however, results presented varied findings: predominance of altered responses in PWS; no significant difference between PWS and fluent individuals regarding the P300 latency; statistically significant higher amplitudes of the P300 wave on left hemisphere of PWS; significant increase on absolute latency of waves I, III and V and interpeaks I-III and I-V on the ABR of PWS 8, 9, 10, 11, 12.

Thus, it is important to characterize the hearing of this population through AEP in order to clarify possible correlations between auditory aspects and fluency. Therefore, the purposes of this study were to characterize the auditory evoked potentials of short (BAER), middle (MLR), and long latencies (Cognitive Potential - P300) in PWS, comparing to fluent individuals; and to verify the potentials progress front to speech therapy.

\section{Method}

The present study was approved by the Ethics Committee of the Institution (CAPPesq HCFMUSP 1021/03). All participants signed the Free and Informed Consent Form - in which all procedures performed were described - consenting participation in the study and dissemination of the results.

Participants were referred by the Laboratory of Speech, Language and Hearing Sciences Research in Fluency, Motricity and Orofacial Functions. The study was developed at the Laboratory of Speech, Language and Hearing Sciences Research in
Auditory Evoked Potentials. Both Laboratories are part of the Speech, Language and Hearing Sciences Course of the Physical Therapy, Speech, Language and Hearing Sciences and Ocuppational Therapy Department of School of Medicine, University of São Paulo.

\section{Subjects}

Sixteen male and eighteen female subjects with ages ranging between 18 and 30 years were evaluated. Eight PWS composed the study group (SG) and eight fluent individuals composed the control group (CG). The inclusion criteria adopted were: hearing thresholds of up to $20 \mathrm{dBHL}$ at frequencies from 250 to $8000 \mathrm{~Hz}$; and no hearing, neurological or psychiatric complaints.

The groups differentiated only regarding communication disorder: on the SG individuals presented Speech-Language Pathology diagnosis of stuttering and individuals from the CG presented no alterations on oral communication.

\section{Procedures}

After completion of a history questionnaire with the aim of collecting data on hearing complaints and eligibility criteria for the sample - each individual was subjected to inspection of the external ear canal with an otoscope (from Welch Allyn) to assess the conditions for conventional audiological assessment and electrophysiological performance. Pure tone air conduction audiometry was performed in a soundproof booth with warble stimuli. The frequencies tested ranged from 250 to $8000 \mathrm{~Hz}$. The logoaudiometry was performed by means of the Speech Reception Threshold (SRT) and the Speech Recognition Index (SRI). For both procedures an audiometer from Grason-Stadler, Model GSI 61, was used. This assessment was performed for confirmation of normal hearing.

The acoustic immittance measures were composed by tympanometry with probe tone of $226 \mathrm{~Hz}$, and by the acoustic reflex of the stapedius muscle (ipsilateral and contralateral) at frequencies of 500,1000, 2000 and $4000 \mathrm{~Hz}$, performed with a middle ear analyzer from Grason - Stadler, Model GSI33.

A portable system from Bio-Logic, model Traveler Express, was used for AEP measurement. The measurement occurred after preliminary skin cleaning with abrasive paste and attachment of electrodes to the skin by means of electrolytic paste and adhesive tape (micropore $®$ ). The electrode 
positions were pre-determined by the examination protocols. The electrodes impedance values were verified and they should situate below $5 \mathrm{kOhms}$. The acoustic stimulus was presented by a pair of headphones TDH - 39, which elicited the responses. The tests were conducted in quiet environment. The electrodes placement to capture the AEP followed the IES 10-20 (International Electrode System) standard (13).

The acoustic stimulus used on BAER was the click of rarefied polarity. It was presented monaurally at $80 \mathrm{dBnHL}$, and with speed of presentation of 19 clicks per second and duration of 0.1 milliseconds (ms) each. A total of 2000 stimuli were presented. The window used for recording was of $10 \mathrm{~ms}$. The electrodes were positioned on the forehead (Fpz) and on left and right mastoids (M1, M2). The absolute latencies of waves I, III, V and interpeaks I-III, III-V, I-V were analyzed.

To capture the MLR, the stimuli were presented monaurally at speed of 9.9 clicks per second and at intensity of $70 \mathrm{dBnHL}$. Two sweeps of 1000 clicks each were presented and the recording window used was $100 \mathrm{~ms}$. The electrodes were arranged at mastoids (M1, M2), temporal lobes or left and right coronal regions $(\mathrm{C} 3, \mathrm{C} 4)$, vertex $(\mathrm{Cz})$ and forehead (Fpz - ground or common). The stimuli were transmitted by phone and responses were recorded twice in each condition (C3/M1, C4/M1; C3/M2, $\mathrm{C} 4 / \mathrm{M} 2)$. Latencies of $\mathrm{Na}$ and $\mathrm{Pa}$ waves, and amplitudes $\mathrm{Na}-\mathrm{Pa}$ on the four mentioned conditions were analyzed.

Electrodes were positioned on left and right mastoids (M1, M2), vertex (Cz) and forehead (Fpz) for P300 obtainment. The acoustic stimulus used was the tone-burst at $70 \mathrm{~dB} \mathrm{HL}$ at frequencies of $1000 \mathrm{~Hz}$ (frequent stimulus) and $1500 \mathrm{~Hz}$ (rare stimulus), randomly presented by the computer in a recording window of $512 \mathrm{~ms}$. The rare stimulus occurred from 15 to $20 \%$ of the total of 300 stimuli. Presence and absence of such potential were verified, and latency and amplitude were analyzed when present.

\section{Result Analysis}

The BAER results were classified as normal and altered according to the latency values of waves I, III and V and interpeaks I-III, III-V and I-V for adults - as proposed by the Evoked Potential User Manual for the Bio-Logic equipment, utilizing two standard deviations.

The results of MLR were classified as normal and altered according to latency values of waves
$\mathrm{Na}(15$ - $25 \mathrm{~ms})$ and $\mathrm{Pa}$ (25 - $40 \mathrm{~ms}$ ) according to Chermark Musiek(14), and amplitudes Na-Pa between the ipsilateral and contralateral modalities, two by two (C3/M1, C4/M2, C3/M2, C4/M1). The P300 was classified as normal and altered according to latency values between 225 to $365 \mathrm{~ms}$, according to McPherson (15).

In the comparative analysis of results obtained in the assessments before and after therapy, the development of potentials were classified as decrease, increase or maintenance of latency and amplitude values of SG and CG. It is important to highlight that values that suggest improvement in neural transmission of auditory stimuli are the ones of decrease of latency values (in ms) and increase of amplitude values (in $\mu \mathrm{v}$ ).

The comparative result analysis of assessments before and after therapy was performed based on six subjects for each group (two individuals from SG did not return for the second evaluation). Statistical analysis was performed using the chisquare and Mann-Whitney tests. The significance level was of $5 \%$.

\section{Results}

The AEP analysis on the evaluations before and after Speech-Language therapy for SG and CG evidenced that BAER changed (increase of wave I latency) in one individual (16.7\%) of SG. No changes were observed on CG. Regarding MLR, changes were observed in two subjects (33.3\%) from SG (increased latency of $\mathrm{Na}$ wave in one subject at positions $\mathrm{C} 3$ / $\mathrm{M} 1$ and C4/M1 and in one subject in C4/M2) and in one subject from CG (increased latency of Na wave). The $\mathrm{Pa}$ wave latency increased at position $\mathrm{C} 3 / \mathrm{M} 2$ in one subject $(12.5 \%)$ from SG. No changes were observed in CG. The P300 latency changed in two subjects from SG. No changes were observed in CG.

As noticed in Table 1, it was observed that, on the result comparison between before and after SpeechLanguage therapy (assessments 1 and 2) on BAER, there was a predominance of wave I latency decrease in SG (66.7\%). However, such difference was not statistically significant $(p=0.155)$. For wave III, there was a predominance of latency maintenance on SG $(41.7 \%)$ with no statistical significance $(p=0.151)$. No statistically significant difference was found between SG and CG in the comparative analysis of wave V latency $(\mathrm{p}=0.160)$, despite the predominance of increase observed in both groups (83.3\% in SG and $50 \%$ in CG). There was predominance on increase of interpeaks I-III, III-V and I-V, however such increase was not statistically significant $(p=0.158, p=0.607$ 
and $\mathrm{p}=0.621$, respectively).

Results of the qualitative data obtained on MLR for each modality (C3 e C4), before and after speech therapy (assessments 1 and 2) in both groups, are shown in Table 2. Regarding the Na wave latency, at the $\mathrm{C} 3$ position, an increase predominance $(50 \%)$ was observed in SG and a decrease (41.7\%) in CG although not statistically significant ( $\mathrm{p}=0.497)$. In $\mathrm{C} 4$, there was a decrease predominance in both groups (50\% in SG and $66.7 \%$ in $\mathrm{CG}$ ), also not statistically significant ( $\mathrm{p}=$ 0.683). At both positions, a predominance of increase in latency of Pa wave in SG was observed - statistically significant only at C3 ( $\mathrm{p}=0.041)$. No statistically significant alterations were observed regarding amplitude $\mathrm{Na} / \mathrm{Pa}$ at $\mathrm{C} 3(\mathrm{p}=0.408)$, and $\mathrm{C} 4(\mathrm{p}=0.682)$.

Results of the qualitative analysis of latency and amplitude of P300 wave in SG and CG are described in Table 3.
Comparative analysis of latency values of P300 wave showed a non statistically significant predominance $(\mathrm{p}=0.287)$ of decrease in both groups $(58.3 \%)$. Regarding amplitude values, no statistically significant difference was observed $(p=0.621)$.

With the aim of verifying the improvement in latency and amplitude, the values obtained on the hearing electrophysiological assessment before Speech-Language therapy were subtracted from those obtained on the assessment after therapy. Therefore, the difference was positive where an increase in measures after therapy was observed and negative where a decrease was observed. The average differences observed with regard to latency were of 15.33 for SG and -8.00 for CG. Averages of 1.52 for SG and -3.10 for CG were observed for the variable amplitude. No statistically significant differences were found when comparing the variables latency $(p=0.751)$ and amplitude $(p=0.84)$ between CG and SG.

TABLE 1. Comparative analysis between assessments 1 and 2 of waves I, III, V latencies, and interpeaks I-III, III-V, I-V of BAER in SG and CG.

\begin{tabular}{|c|c|c|c|c|c|c|c|c|c|c|c|c|}
\hline & \multicolumn{6}{|c|}{ STUDY GROUP (SG) } & \multicolumn{6}{|c|}{ CONTROL GROUP (CG) } \\
\hline & I & III & $\mathbf{V}$ & I-III & III-V & I-V & I & III & $\mathbf{V}$ & I-III & III-V & I-V \\
\hline Decrease & $\begin{array}{c}8 \\
(66,7 \%) \\
\end{array}$ & $\begin{array}{c}3 \\
(25 \%) \\
\end{array}$ & $\begin{array}{c}2 \\
(16,7 \%)\end{array}$ & $\begin{array}{c}4 \\
(33,3 \%) \\
\end{array}$ & $\begin{array}{c}2 \\
(16,7 \%)\end{array}$ & $\begin{array}{c}2 \\
(16,7 \%)\end{array}$ & $\begin{array}{c}4 \\
(33,3 \%) \\
\end{array}$ & $\begin{array}{c}6 \\
(50 \%)\end{array}$ & $\begin{array}{c}4 \\
(33,3 \%) \\
\end{array}$ & $\begin{array}{c}4 \\
(33,3 \%) \\
\end{array}$ & $\begin{array}{c}4 \\
(33,3 \%) \\
\end{array}$ & $\begin{array}{c}4 \\
(33,3 \%) \\
\end{array}$ \\
\hline Increase & $\begin{array}{c}4 \\
(33,3 \%)\end{array}$ & $\begin{array}{c}4 \\
(33,3 \%)\end{array}$ & $\begin{array}{c}10 \\
(83,3 \%)\end{array}$ & $\begin{array}{c}8 \\
(66,7 \%)\end{array}$ & $\begin{array}{c}7 \\
(58,3 \%)\end{array}$ & $\begin{array}{c}8 \\
(66,7 \%)\end{array}$ & $\begin{array}{c}6 \\
(50 \%)\end{array}$ & $\begin{array}{c}5 \\
(41,7 \%)\end{array}$ & $\begin{array}{c}6 \\
(50 \%)\end{array}$ & $\begin{array}{c}5 \\
(41,7 \%)\end{array}$ & $\begin{array}{c}5 \\
(41,7 \%)\end{array}$ & $\begin{array}{c}6 \\
(50 \%)\end{array}$ \\
\hline Maintenanc & 0 & $\begin{array}{c}5 \\
(41,7 \%)\end{array}$ & 0 & 0 & $\begin{array}{c}3 \\
(25 \%)\end{array}$ & $\begin{array}{c}2 \\
(16,7 \%)\end{array}$ & $\begin{array}{c}2 \\
(16,7 \%)\end{array}$ & $\begin{array}{c}1 \\
(8,3 \%)\end{array}$ & $\begin{array}{c}2 \\
(16,7 \%)\end{array}$ & $\begin{array}{c}3 \\
(25 \%)\end{array}$ & $\begin{array}{c}3 \\
(25 \%)\end{array}$ & $\begin{array}{c}2 \\
(16,7 \%)\end{array}$ \\
\hline
\end{tabular}

TABLE 2. Comparative analysis between assessments 1 and 2 of $\mathrm{Pa}$ and $\mathrm{Na}$ wave latencies and Na-Pa amplitude of MLR in SG and CG at positions $\mathrm{C} 3$ e $\mathrm{C} 4$.

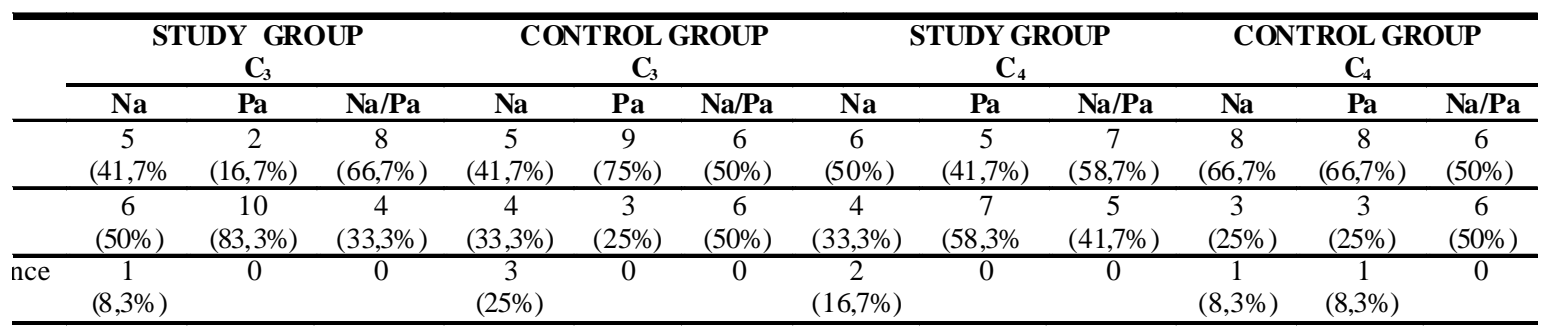

TABLE 3. Comparative analysis between assessments 1 and 2 of P300 latency and amplitude in SG and CG.

\begin{tabular}{|c|c|c|c|c|}
\hline \multirow[t]{2}{*}{ P300 } & \multicolumn{2}{|c|}{ STUDY GROUP } & \multicolumn{2}{|c|}{ CONTROL GROUP } \\
\hline & Latency & Amplitude & Latency & Amplitude \\
\hline Decrease & $7(58,3 \%)$ & $6(50 \%)$ & $7(58,3 \%)$ & $5(41,7 \%)$ \\
\hline Increase & $3(25 \%)$ & $5(41,7 \%)$ & $5(41,7 \%)$ & $7(58,3 \%)$ \\
\hline Maintenance & $2(16,7 \%)$ & $1(8,3 \%)$ & 0 & 0 \\
\hline
\end{tabular}




\section{Discussion}

In general, the observed results showed that, already on the first electrophysiological evaluation, changes on AEP of four subjects $(66.7 \%)$ from SG were observed, being that one same subject presented alterations on BAER and MLR and one subject presented alteration only on MLR. Regarding the P300, two subjects from SG presented increase in latency (33.3\%). One subject (16.7\%) from CG presented MLR alteration. Therefore, a higher occurrence of altered results on AEP is verified in SG when compared to CG - although this difference was not statistically significant. Such findings are in accordance with a study conducted by Blood and Blood (8), who compared the BAER of PWS and fluent subjects, with predominance of altered responses in the SG.

Khedr et al. (11) found a statistically significant increase in latencies of waves I, III and V and interpeaks I-III and I-V in the BAER of PWS and found no significant differences in the P300 as compared to the control group. The present study supports, in part, the previously mentioned one. Although BAER alterations were predominantly found, these were not statistically significant. Regarding the analyzed P300 parameters, the present study is consistent with the one mentioned above, once the authors found no significant alterations in SG and CG.

Regarding the BAER results, findings of the present study showed similar to those obtained by Dietrich et al. (16), who found no statistically significant differences on BAER latencies and

\section{References}

1. Nicolosi L, Harryman E, Kresheck J. Vocabulário dos distúrbios da comunicação, fala, linguagem e audição. $3^{\mathrm{a}}$ ed. Porto Alegre: Artes Médicas; 1996.

2. Fox PT, Ingham RJ, Ingham JC, Hirsch TB, Downs JH, Martin C, Jerabek P, Glass T, Lancaster JL. A PET study of the neural systems of stuttering. Nature 382, 158-162 (11 Jul 1996) | doi:10.1038/382158a0.

3. Howel P, Williams SM. Development of Auditory Sensibility in Children who Stutter and Fluent Children.Ear \& Hearing. 2004;25(3):265-73.

4. Jerger J, Musiek FE. Report of the consensus conference on the diagnosis of auditory Processing disorders in schoolaged children. Journal of the American Academy of Audiology. 2000;11:467-74. amplitudes and on the MLR Pa wave latency in PWS when compared to the control group.

Regarding the comparative study of AEP between assessments (before and after Speech-Language Therapy), the present study showed no statistically significant difference between SG and CG. There was a predominance of decrease in latencies of wave I of BAER and of P300 in the SG. This finding indicates the occurrence of functional neuroplasticity, reflecting better neuronal promptness for auditory stimuli.

Andrade et al. (12) conducted a pilot study aiming to investigate the relationship between stuttering improvement and brain activity, using the assessment of P300 in three PWS. They concluded that this population can show different patterns of inter-hemispheric activity in a task with P300 after Speech-Language therapy. This finding is in accordance with the present ones regarding reduction of P300 latency and reduction of wave I of BAER.

We emphasize the need for more studies on such correlation, as the parameters in electrophysiological evaluation are many, besides the complexity of factors involved in disfluency.

\section{Conclusion}

There was a trend towards altered electrophysiological responses in PWS. Regarding the potentials front to Speech-Language therapy, wave I latency of BAER and of P300 were the parameters that best revealed the neuronal plasticity.

5. Hayes EA, Warrier CM, Nicol TG. Neural plasticity following auditory training in children with learning problems. Clinic Neurophysiology. 2003;114:673-84.

6. Kalil RE. Synapse formation in the developing brain. Scientific American. 1989;261:76-85.

7. Kraus N. Auditory pathway enconding and neural plasticity in children with learning. problems. Audiol. Neurotol. 2001;6(4):221-7.

8. Blood IM, Blood GW. Relationship between stuttering severity and brainstem-evoked response testing. PerceptMot-Skills. 1984 Dec 59(3):935-8.

9. Ferrand CT, Gilbert HR.\& Blood GW. (1991). Selected aspects of central processing and vocal motor function in stutterers and nonstutterers: P300, laryngeal shift, and vibratory onset. Journal of Fluency Disorders. 16(2/3),10115 
10. Morgan MD, Cranford JL, Burk K. P300 event-related potentials in stutterers and nonstutterers. J of SpeechLanguage and Hear. Research. 1997;40:1334-40

11. Khedr M, El Nasser WA, Abdel-Haleem EK, Bakr MS, Trakhan MN. Evoked potentials and eletroencephalography in Stuttering.Folia - Phoniatr Logop. 2000 Jul-Aug 52(4);178-86.

12. Andrade CRF, Sassi FC, Matas CG, Neves IF, Martins VO. Potenciais evocados auditivos pré e pós-tratamento em indivíduos gagos: estudo piloto. Pró-Fono Revista de Atualização Científica. 2007 out-dez 19(4):401-5.

\section{Bibliography}

Brayner ICS. Aplicação do paradigma auditivo "Oddball" no estudo do P300: normatização para faixa etária de 7-14 anos e avaliação de crianças com dificuldade de aprendizagem com e sem transtorno de déficit de atenção/hiperatividade. [Dissertação]. Campinas: Universidade Estadual de Campinas; 2003.
13. Brad A. Stach. Comprehensive dictionary of audiology ilustrated. $2^{\mathrm{a}}$ ed. Thomson Delmar Learning; 2003.

14. Chermark G, Musiek FE. Central auditory processing. San Diego: Singular Publishing Press; 1997.

15. McPherson DL. Late potentials of the auditory system. San Diego: Singular Publishing Group Inc; 1996.

16. Dietrich S, Barry SJ, Parker DF. Middle latency auditory responses in males with Stutter. Journal of Speech and Hearing research. 1995;38:5-17.

Leite RA. Avaliação eletrofisiológica da audição em crianças com distúrbio fonológico pré e pós terapia fonoaudiológica. [Dissertação]. São Paulo: Universidade de São Paulo; 2006. 